\title{
STRATEGI PEMASARAN DAN PENDAMPINGAN MANAJEMEN USAHA KELOMPOK USAHA KECIL KERUPUK DI KENJERAN KOTA SURABAYA
}

\author{
Riyadi Nugroho $\left.{ }^{1 *}\right)$, Siti Mujanah ${ }^{1}$ \\ ${ }^{1}$ Fakultas Ekonomi dan bisnis, Universitas 17 Agustus 1945 Surabaya \\ ${ }^{*}$ Korespondensi: riyadi@untag-sby.ac.id
}

Diterima 4 November 2020 / Disetujui 5 Desember 2020

\begin{abstract}
ABSTRAK
Kegiatan pengabdian masyarakat ini bertujuan untuk menentukan strategi pemasaran dan pendampingan manajemen usaha serta pemberian Teknologi Tepat Guna (TTG) bagi kelompok usaha kecil yang bergerak di bidang kerupuk di Kenjeran, Kota Surabaya. Permasalahan yang dihadapi oleh kelompok UMKM kerupuk di kenjeran ini adalah penjualan yang macet total karena tidak tengkulak yang datang membeli kerupuk karena adanya pandemi COVID 19 yang melanda, sehingga tidak ada kegiatan penjualan di tempat wisata pantai Kenjeran, selain itu juga rendahnya kemampuan dalam mengelola usaha, tanpa ada perencanaa, pengorganisasi, pembukuan dan evaluasi. Melihat situasi tersebut maka perlu adanya transfer of knowledge dan pendampingan guna menjalankan fungsi manajemen, sehingga kegiatan PKM ini dilakukan dengan memberikan teknologi untuk berjualan online berupa alat Hand phone, Inpulse Sealer, Label produk, dan plastik kemasan, kemudian diberikan pelatihan tentang packaging, dan menjual online melalui Tokopedia dan Sophe. sehingga saat ini sudah ada pembelian melalui Tokopedia Shoppee.
\end{abstract}

Kata kunci: Strategi pemasaran, TTG, packaging, dan manajemen usaha,

\section{PENDAHULUAN}

Industri Mikro kecil dan menengah merupakan bagian integral dunia usaha nasional dan mempunyai kedudukan, potensi, dan peranan yang sangat penting dan strategis dalam meningkatkan perekonomian secara nasional. Selama in Usaha mikro kecil selain berperan dalam meningkatkan ekonomi nasional juga dapat mengurangi pengangguran. UMKM juga terlibat dalam pemerataan hasil pembangunan. Ini membuktikan bahwa UMKM kembali terbukti tidak terpengaruh oleh krisis keuangan global (Profil bisnis UKM, 2015). Namun sejak awal tahun 2020 UMKM di Indonesia telah dihadapkan pada virus corona atau COVID-19 yang telah menyerang seluruh dunia, termasuk Indonesia. Virus telah menginfeksi kesehatan masyarakat sehingga membuat kondisi kesehatan masyarakat memburuk.

Wabah virus corona pertama kali muncul di Indonesia pada awal Maret lalu. Setelah jumlah korban positif meningkat, hingga Juni 2020 yang dilakukan survei ini, jumlah virus yang menginfeksi bangsa Indonesia adalah 55.092, dan setiap hari meningkat secara signifikan (Fatoni, 2020). Pemerintah Indonesia menghimbau masyarakat untuk melakukan berbagai aktivitas dari rumah, antara lain bekerja dari rumah, belajar dari rumah, dan beribadah dari rumah. Hal tersebut tentunya berdampak pada kegiatan ekonomi 
masyarakat. Indeks pasar saham anjlok, Rupiah melemah, dan bisnis di sektor riil semakin bergelut. Oleh karena itu, COVID19 berpengaruh signifikan terhadap pendapatan usaha mikro yang tersebar luas di Indonesia. Usaha Mikro, Kecil, dan Menengah (UMKM) di Indonesia memberikan kontribusi yang signifikan bagi perekonomian Indonesia, namun periode pandemi ini berdampak sangat negatif bagi Indonesia (Crismawa, 2020). Apalagi pengusaha yang pernah mengalami penurunan atau bahkan terpaksa tutup perusahaan akan lebih banyak bekerja akibat virus corona. Dalam kondisi seperti ini, para pengusaha harus berpikir kritis dan kreatif dengan mengembangkan bisnis kreatif yang bisa dilakukan dari rumah dan dibutuhkan oleh banyak konsumen.

UMKM lokal memang seharusnya mendapatkan perhatian besar dari berbagai pihak, karena selain dapat menghidupkan ekonomi masyarakat juga proses produksinya menggunakan sumber-sumber bahan pertanian dan bahan lokal lainnya sehingga perputaran terhadap petani atau produsen bahan baku sampai ke produsen barang jadi yang siap daipasarkan di masyarakat. Pemasaran UMKM umumnya juga berada dalam lingkup domestik yang terbatas. Ketersediaan bahan baku lokal bagi industri kecil dan menengah merupakan keunggulan tersendiri yang memungkinkan dapat beroperasi secara efisien dan juga bisa memberdayakan masarakat lokal sehingga meningkatkan kesejahteraan masyarakat secara luas (Mujanah, 2015).

Fenomena di atas menunjukkan bahwa betapa pentingnya keberadaan usaha kecil untuk menciptakan stabilitas ekonomi melalui penciptaan lapangan kerja dan pemerataan pendapatan, namun karena tingkat produktivitasnya yang rendah menyebabkan nilai tambah bagi kegiatan ekonomi menjadi rendah.
Produlttivitas dan nilai tambah usaha kecil yang rendah dikarenakan faktor daya saing yang rendah dari produk UMKM itu sendiri, kualitas produk yang rendah kompetensi UMKM yang kurang dikarenakan kurangnya profesionalisme dari pelaku yang memerlukan pembinaan dan pendampingan dari berbagai pihak.

Fenomena di atas menunjukkan betapa pentingnya keberadaan UMKM dalam menciptakan stabilitas ekonomi melalui penyerapan tenaga kerja dan pendapatan masyarakat, namun karena adanya COVID 19 menjadikan tingkat produktivitas rendah kegiatan ekonomi menjadi lumpuh. Hal ini memerlukan strategi penanganan dengan seriuos agar UMKM tetap dapat produktif dan menghasilkan ekonomi terutama dengan strategi pemasaran yang mudah di raih oleh konsumen.

Salah satu UMKM di Kota Surabaya yang sedang serius mengalami permasalahan penjualan di masa Covid 19 ini adalah kelompok usaha kerupuk di Kenjeran Surabaya, karena kerupuk merupakan salah satu makanan pelengkap ketika makan dan banyak digemari oleh para konsumen. Rasanya yang gurih dan teksturnya yang sangat renyah, menjadikan kerupuk sebagai salah satu pelengkap aneka makanan yang banyak digemari oleh banyak konsumen. Kebanyakan masyarakat Indonesia merasa kurang lengkap jika makan tanpa dilengkapi dengan kerupuk. Maka hal ini menimbulkan peluang besar bagi produsen kerupuk di Surabaya, sehingga pemerintah Kota Surabaya dengan serios juga telah mengembangkan sentra produksi kerupuk sebagai peluang usaha yang cukup potensial bagi para pelaku usaha demi kesejahteraan masyarakat.

Kecamatan Kenjeran ini memang daerahnya dekat dengan pantai dan banyak nelayang yang menghasilkan berbagai hasil laut ikan, udang, kerang, cumi, lorjuk, 
kepiting dan lain-lainya yang bisa di dapatkan sebagai bahan pembuat krupuk seperti lerupuk udang, krupuk kerang, kerupuk cumi dan jenis krupuk lainnya.

Sentral UMKM Krupuk di Kenjeran ini memproduksi 4 (empat) macam jenis krupuk yaitu kupang, kerupuk Cumi-cumi, Kepiting dan kerupuk Lorjuk. Setiap UMKM di sini setiap hari memproduksi sebanyak 60 s/d $100 \mathrm{Kg}$ per 2 (dua) hari sekali, dan selama ini sebagian di ambil tengkulak serta sebagian di titipkan di stand penjual krupuk di daerah wisata pantai Kenjeran. Berdasarkan hasil survey jika dilihat dari cara menjual produk hanya menunggu tengkulak datang sehingga tidak bisa menentukan harga sendiri karena harga di tetapkan oleh tengkulak dengan keuntungan yang tidak leluasa. Apalagi di masa COVID 19 tengkulak tidak pernah datang untuk membei kerupuk dan tempat wisata di tutup sehingga produksi berhenti total. Untuk itu perlu dilakukan bantuan dengan memberikan pelatihan menjual secara online beserta pelatihan dan pemberian perangkatnya, oleh karena itu dalam kegiatan PKM ini kegiatan yang dilakukan adalah memberikan TTG alat untuk pemasaran online, memberikan pelatihan packaging, pemasaran online serta pendampingan manajemen usaha dan pembukuan sederhana.

\section{Permasalahan Mitra}

Kelompok Usaha Kerupuk di Kenjeran Kota Surabaya ini mampu berproduksi aneka kerupuk dengan b4 (empat) variasi produk kerupuk hasil laut dengan baik, namun kendalanya pemasaran, sehingga beberapa permasalahan yang dihadapi antara lain adalah sebagai berikut:

1. Penjualan yang dilakukan selama ini hanya menunggu tengkulak datang, sehingga pada masa Pandemi COVID 19 penjualan berhenti karena tidak ada tengkulak yang datang.
2. Penjualan krupuk yang dilakukan secara curah atau dengan kiloan kurang memberikan keuntungan lebih.

3. Usahanya belum di kelola dengan baik, tidak adanya perencanaan, pengorganisasian, pengadministrasian keuangan, dan apalagi evaluasi.

\section{Tujuan Kegiatan}

Berdasarkan permasalahan yang dihadapi oleh kelompok Usaha Kerupuk diatas, maka tujuan dari kegiatan PKM ini antara lain adalah sebagai berikut:

\section{Memberikan Teknologi Tepat} Guna (TTG) bagi kelompok usaha kerupuk sebagai alat dalam penjualan online. TTG yang diberikan adalah Handphone untuk menjual secara online, packaging berupa label, plastik dan perekat plastik atau Impuls sealer.

2. Untuk meningkatkan penjualan, maka telah dilakukan Pelatihan membuat packaging untuk Pemasaran online dan juga pelatihan pemasaran online

3. Membantu mendaftarkan pemasaran produk di Tokopedia dan Shoppee dan mempromosikanya melalui Topadd.

4. Pendampingan Pengelolaan Usaha dan memberikan pemahaman bagaimana mengelola usaha agar efektif dan efisien.

5. Mengadakan pelatihan Manajemen Keuangan terhadap Kelompok UKM kerupuk dengan harapan setiap anggota kelompok dapat mengelola keuangan dan melakukan pembukuan sederhana.

6. Dengan Program kemitraan Masyarakat ini diharapkan kelompok UMKM Kerupuk di Kenjeran dapat meningkatkan penjualan dengan harapan mitra dapat meningkatkan kesejahteraanya. 


\section{METODE PELAKSANAAN}

Metode yang digunakan dalam kegiatan PKM ini adalah Metode Problem solving yaitu mencari permasalahan dan memberikan solusi yang ditawarkan dan di setujui mitra untuk dilaksanakan. Menurut Abdul Majid (2013) bahwa Metode Problem Solving merupakan cara memberikan pengertian dengan menstimulasi seseorang untuk memperhatikan, menelaah, dan berfikir tentang suatu masalah untuk selanjutnya menganalisis masalah tersebut sebagai upaya untuk memecahkan masalah. Metode problem solving merupakan salah satu dasar teoritis yang menjadikan masalah sebagai isu utamanya dalam pembahasan. Sejalan dengan itu Utomo Dananjaya (2013:
129) juga memiliki penjelasan tentang Metode Problem Solving yaitu upaya peningkatan hasil melalui proses secara ilmiah untuk menilai, menganalisis, dan memahami keberhasilan. Oleh karena itu, untuk menyelesaikan sebuah masalah seseoranag harus dibiasakan berpikir secara mandiri.

Permasalahan yang dihadapi oleh mitra adalah penjualan yang berhenti karena adanya pandemi COVID 19. Sehingga penyelesaian dapat dilakukan dengan mencari strategi pemasaran yang tepat dan memberikan pendampingan tentang manajemen usaha serta pembukuan keuangan sederhana. Kegiatan untuk mewujudkan atas solusi yang ditawarkan disajikan pada Tabel 1.

Tabel 1: Metode Pelaksanaan kegiatan

\begin{tabular}{|c|l|l||}
\hline No & \multicolumn{1}{|c|}{ Kegiatan yang dilaksanakan } & \multicolumn{1}{c|}{ Indikator Hasil } \\
\hline 1 & $\begin{array}{l}\text { Koordinasi antara anggota Tim } \\
\text { pelaksana dengan pihak mitra }\end{array}$ & $\begin{array}{l}\text { Kesepakatan tentang rencana } \\
\text { kegiatan dan bentuk partisipasi mitra }\end{array}$ \\
\hline \hline 2 & Pengadaan TTG & $\begin{array}{l}\text { Pembelian Handphone Android untuk } \\
\text { berjualan secara online, dan mesin } \\
\text { ImpulseSealer untuk packaging. }\end{array}$ \\
\hline 3 & Penyerahan alat ke mitra & Berita acara serah terima alat \\
\hline 4 & Membantu mendesain kemasan & Pengadaan Desain dan cetak kemasan \\
\hline 5 & Memasarkan kerupuk secara online & $\begin{array}{l}\text { Telah di daftarkan Produk Kerupuk } \\
\text { Aneka Hasil Laut Hotim di Tokopedia } \\
\text { dan Shopee dan pelatihan } \\
\text { mengoperasikanya }\end{array}$ \\
\hline 6 & $\begin{array}{l}\text { Pelatihan memasarkan produk } \\
\text { melalui online }\end{array}$ & $\begin{array}{l}\text { Telah di pahami cara menjual produk } \\
\text { Kerupuk secara online di Tokopedia } \\
\text { dan Shoppee }\end{array}$ \\
\hline 7 & Pendampingan Manajemen & $\begin{array}{l}\text { Mengelola usaha dengan tepat, } \\
\text { membuat packaging dan memasarkan } \\
\text { produk dengan lancar }\end{array}$ \\
\hline \hline 9 & $\begin{array}{l}\text { Pendampingan Pembukuan } \\
\text { Sederhana }\end{array}$ & $\begin{array}{l}\text { Mitra telah melakukan pembukuan } \\
\text { keluar masuk uang usaha }\end{array}$ \\
\hline \hline & Monitoring Evaluasi & $\begin{array}{l}\text { Melakukan monitoring dan evaluasi } \\
\text { serta memberikan bantuan jika } \\
\text { terjadi permaslahan lebih lanjut. }\end{array}$ \\
\hline \hline
\end{tabular}


Mitra dalam kegiatan ini selalu aktif berpartisipasi dalam pelaksanaan kegiatan ini dalam setiap pelatihan dan mampu mengimplementasikan hasil pelatihan secara baik.

\section{HASIL DAN PEMBAHASAN}

Kegiatan pengabdian masyarakat ini dimulai dengan melakukan koordinasi dengan Mitra Kelompok Usaha Kecil Krupuk di Kenjeran Surabaya, koordinasi dilakukan untuk membuat kesepakatan bersama tentang kegiatan yang akan dilakukan dalam memecahkan permasalahan yang dialami oleh UMKM Kerupuk, dari hasil koordinasi mendapatkan kesepakatan tentang kegiatan PKM yang akan dilaksanakan yaitu dengan cara memberikan pelatihan pemasaran online, pendampingan manajemen usaha, Pendampingan pembukuan sederhana serta pengadaan Teknologi Tepat Guna. Teknologi yang di berikan adalah alat untuk pemasaran online berupa Handphone Android, mesin Impuls seal berukuran $30 \mathrm{~cm}$, label produk untuk packaging yang di desain dan di cetak dengan ukuran $1 / 2 \mathrm{Kg}, 1 \mathrm{Kg}$ dan $5 \mathrm{Kg}$., selain itu juga diberikan plastik pembungkus kerupuk sebanyak tiga macam ukuran yaitu untuk $1 / 2 \mathrm{Kg}$, untuk 1 Kg dan untuk $5 \mathrm{Kg}$ Kerupuk.

Kegiatan ini sasaran utamanya adalah bagaimana kelompok UMKM kerupuk ini bisa menjual produknya, di masa pandemy COVID seperti ini penjualan offline masih belum memungkinkan maka harus dilakukan penjualan secara online. Pemasaran online dianggap mampu mengembangkan penjualan usaha secara optimal dengan biaya yang jauh lebih ringan dibandingkan secara offline (Anonim, 2019).

Pemasaran online merupakan strategi pemasaran yang menggunakan jaringan internet. Kegiatan pemasaran dapat dilakukan dengan memanfaatkan media sosial, website, email, bahkan augmented reality. Hal ini dapat dilakukan dengan iklan berbayar, konten berkualitas atau sekadar posting-an sederhana melalui media online.

\section{Kegiatan yang telah dilakukan}

Kegiatan Pengabdian Masyarakat ini telah dilakukan dengan pengadaan Teknologi Tepat Guna berupa 1 unit Hand Phone, 1 unit Inpulse Sealer, 500 lbr Label kemasan, dan plastik kemasan kerupuk. Kegiatan ini dilakukan dengan memberikan solusi dalam permasalahan pemasalahan mengingat selama pandemi timbul sampai 6 bulan berikutnya tidak ada penjualan karena tidak ada tengkulak yang datang untuk membeli, dan juga tidak lagi bisa menitipkan kerupuk di toko-toko atau stand di daerah wisata mengingat tidak ada kunjungan wisatawan di lokasi tersebut. Untuk itu kegiatan pelatihan penjualan online di berikan dengan melakukan pengadaan Handphone sebagai alat menjual online, sehingga UKM mampu menjual produknya melalui online. Penggunaan pemasaran online juga suatu cara yang menghemat biaya sehingga lebih efisien dan efektif.

Pelatihan telah diberikan tentang Pemasaran online, selain itu juga dibantu untuk mendaftarkan pemasaran produk di market place, yaitu di Tokopedia dan Shoppee. Sebelum lain diberikan pelatihan maka diberikan pendampingan dalam memasarkan Kerupuk secara online terhadap UKM, dan Kerupuk yang dijual ini kita namakan Kerupuk Aneka hasil laut Kerupuk "Hotim", sampai bisa menjual secara mandiri dan hasilnya sudah ada penjualan yang dihasilkan.

Kelompok UMKM Kerupuk di kenjeran ini merupakan salah satu 
kelompok usaha di daerah Kenjeran yang memiliki 4 (empat) macam variasi produk dan di tambah 1 produk berupa Rangginan, sehingga penjualan secara online itu ada 5 macam produk yang terdiri dari Krupuk dengan rasa Kupang, Lorjuk, Cumi-cumi, Kepiting dan Rangginan dan kelompok tersebut di beri nama Kerupuk "Hotim", dan telah di daftarkan di Tokopedia dan Shoppee.

\section{Sebelum Kegiatan Pengabdian Masyarakat}

Jenis kerupuk yang diproduksi oleh kelompok UKM Hotim dengan 4 macam produk kerupuk dan 1 macam produk rengginan. Selama ini hasil produksi dijual secara curah terhadap tengkulak yang datang, sehingga tidak bisa menentukan harga sendiri karena harga sudah ditentukan oleh engkulak yang datang dan membelinya tanpa ada upaya untuk menjual ke toko-toko atau pusat oleholeh. Untuk itu salah satu kegiatan dalam Pengabdian masyarakat ini adalah membantu bagaimana agar UKM Hotim ini bisa menjual sendiri melalui market place secara online. Kerupuk yang dijual secara curah seperti yang dapat di lihat pada gambar 1.
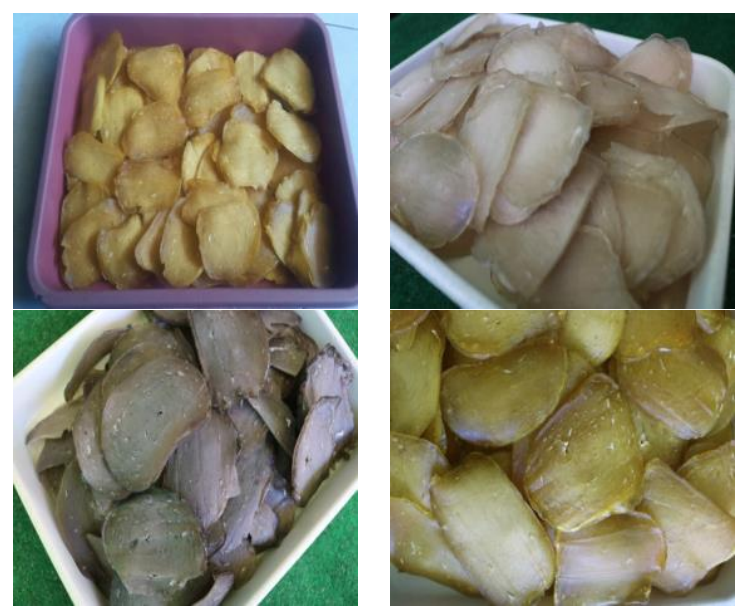

Gambar 1: Aneka Macam Produk Kerupuk yang di jual secara Curah Kiloan

\section{Setelah Kegiatan Pengabdian Masyarakat}

Kegiatan Pengabdian Masyarakat ini adalah mendampingi UMKM Kerupuk "Hotim" dalam menentukan strategi pemasaran secara online, selain itu juga melakukan pendampingan manajemen usaha serta pembukuan keuangan. Beberapa kegiatan tersebut telah dilaksanakan antara lain adalah sebagai berikut:

\section{Desain Label Kemasan}

Kegiatan telah dilakukan dengan membuat desain dan mencetak kemasan terlebih dahulu yang akan digunakan sebagai label dalam packaging produk produk kerupuk "Hotim" sehingga dapat dijual secara eceran secara offline maupun online. Label yang di gunakan terdiri dari beberapa ukuran yaitu $1 / 2$ (setengah) Kilogram, $1 \mathrm{Kg}$ dan juga 5 (lima) kilogram Kerupuk aneka hasil laut "Hotim". Label untuk produk kerupuk ini seperti yang dapat dilihat pada gambar 2 .

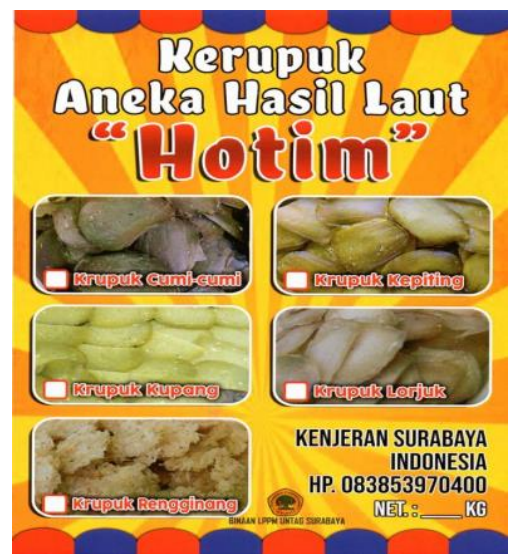

Gambar 2: Desain label untuk Kemasan

\section{Pengadaan TTG untuk Pemasaran Online}

Teknologi tepat guna dalam kegiatan ini dilakukan dengan pengadaan alat yang digunakan dalam pengabdian masyarakat. Menurut Mujanah (2015) dengan memberikan Teknologi Tepat Guna berupa mesin alat produksi maka 
UMKM Jamu tradisional dapat meningkatkan kualitas dan kuantitas produksi sehingga omzet penjualan semakin bertambah. Demikian juga yang diharapkan dalam kegiatan ini dengan memberikan TTG berupa alat memaarkan secara online dapat meningkatkan penjualan sehingga omzet penjualan meningkat.

TTG dalam kegiatan ini diberikan berupa perangkat yang digunakan untuk menjual secara online bisa menggunakan komputer, Laptop atau Smart Phone yang secara praktis bisa dibawa kemana-mana, sehingga dalam kegiatan ini harus melakukan pengadaan teknologi yang dapat digunakan untuk menjual online, dan ternyata kelompok Usaha Kerupuk "Hotim" belum memilikinya, sehingga harus dilakukan pengadaan alat untuk menjual secara online, sehingga kegiatan ini memberikan bantuan alat sebagai alat kegiatan memasarkan produk secara online yaitu Android Samsung A-01 seperti yang dapat dilihat pada gambar 3
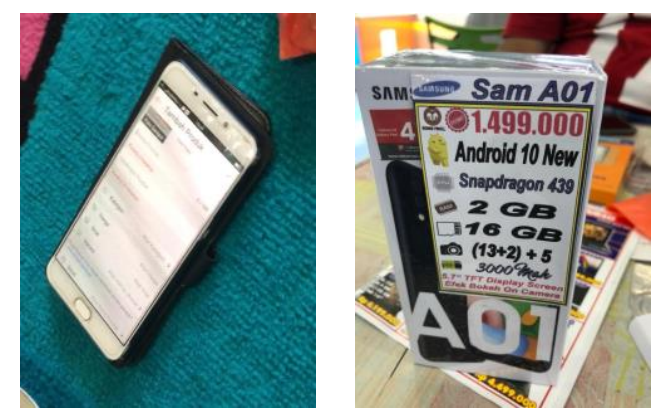

Gambar 3: TTG alat untuk menjual Online

\section{Pengadaan TTG berupa Mesin Inpuls Sealer (Perekat Plastik)}

Pemasaran tidak lepas dari labelling dan packaging, oleh karena itu dalam rangka mempersiapkan produk yang akan dipasarkan maka perlu dilakukan packaging. Untuk membuat packaging kerupuk "Hotim" diperlukan alat perekat plastik atau impuls sealer, oleh karena itu dalam kegiatan inii telah memberikan peralatan mesin perekat plasti atau mesin Impuls Sealer dengan ukuran $30 \mathrm{~cm}$ seperti yang dapat dilihat pada gambar 4 . Inpuls sealer ini digunakan untuk packaging yaitu tepatnya untuk perekat plastik kemasan yang diadakan dalam kegiatan ini yaitu plastik untuk $1 / 2 \mathrm{Kg}$ kerupuk, $1 \mathrm{Kg}$ dan $5 \mathrm{Kg}$ kerupuk yang disiapkan untuk penjualan online mapun online.

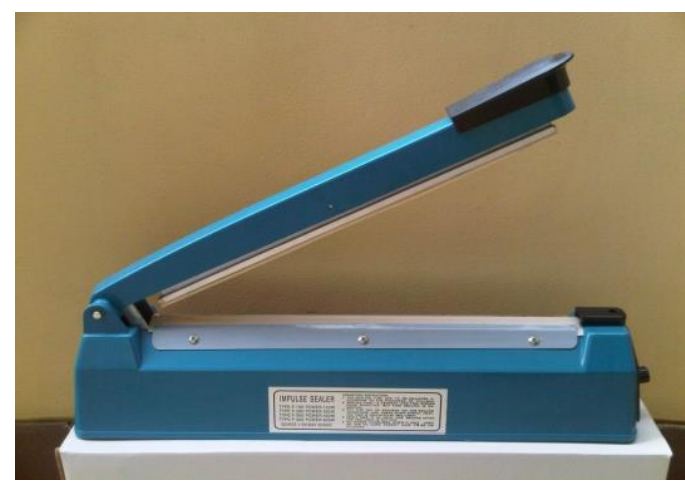

Gambar 4: Impulse Sealer sebagai Alat Perekat Packaging

\section{Kemasan Produk}

Kegiatan Pengabdian masyarakat ini juga telah dilakukan dengan memberikan pelatihan membuat kemasan untuk produk kerupuk terhadap kelompok UKM Hotim, karena dengan memberikan desain kemasan produk bisa berdampak pada penjualan dan kelangsungan usaha (Candraningrat, 2017) sehingga mereka mampu membuat produk dalam kemasan dan menawarkannya di media sosial maupun di marketplace. Kerupuk dalam kemasan yang siap di jual melalui online maupun offline seperti yang dapat dilihat pada gambar 5 .

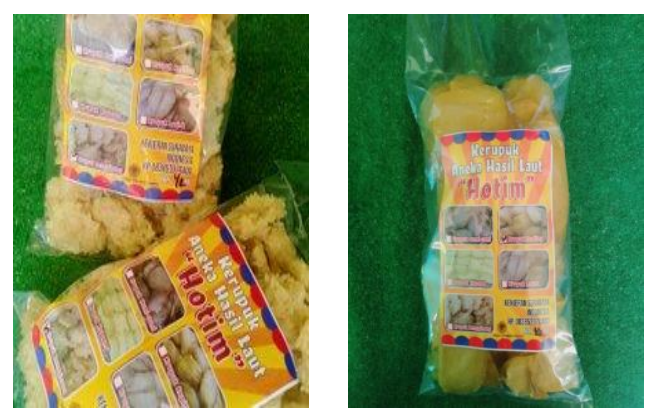



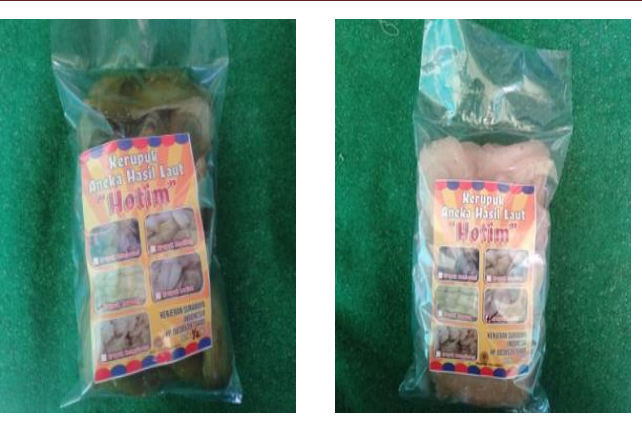

Gambar 5: Kerupuk dalam kemasan

\section{Serah Terima TTG dan Peralatan Packaging}

Teknologi Tepat Guna diberikan terhadap mitra UMKM kerupuk berupa alat yang digunakan untuk penjualan online di marketplace yaitu berupa HP Samsung, A-1, dan Mesin perekat plastik Inpuls Sealer ukuran $30 \mathrm{Cm}$, label untuk kemasan serta plastik kemasan dengan variasi berat $1 / 2 \mathrm{Kg}$., $1 \mathrm{Kg}$. Untuk penjualan eceran dan online, disamping itu ada juga yang berukuran $5 \mathrm{Kg}$. untuk tengkulak yang membeli secara ofline maupun online. TTG tersebut sudah di serah terimakan terhadap mitra seperti yang dapat di lihat pada gambar 6 .
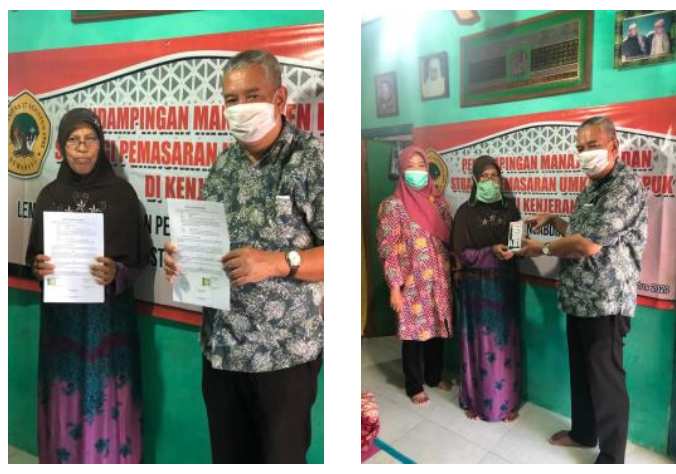

Gambar 6: Serah Terima TTG

\section{Pelatihan}

Pelatihan dalam dalam kegiatan ini terdiri dari pelatihan membuat kemasan, pelatihan pemasaran online dan pelatihan manajemen usaha serta pembukuan keuangan.

\subsection{Pelatihan Membuat kemasan dan Pemasaran online}

Pelatihan pemasaran online diberikan terhadap para anggota kelompok UMKM Kerupuk "Hotim" di Kenjeran setelah TTG dan peralatan diserahkan, kegiatan ini dilakukan oleh tim pelaksana pengabdian masyarakat yang dibantu oleh tenaga ahli dari luar serta dua mahasiswa, seperti yang dapat dilihat pada gambar 7. Pelatihan dilakukan dengan memberikan pemahaman tentang pemasaran online. Menurut Candraningrat (2020) yang telah memberikan pelatihan tentang pemasaran online terhadap UKM PJ Collection menjadikan UKM berhasil melakukan pemasaran dan penjualan secara efektif dan efisien melalui digital marketing dalam kegiatan pengabdian masyarakat, sehingga berdampak pada tingkat pendapatan yang diperoleh UKM PJ Collection, sehingga dapat disimpulkan. Pemberian pelatihan pemasaran dalam kegiatan pengabdian masyarakat ini juga diharapkan dapat meningkatkan penjualan dan berdampak pada penghasilan UMKM Kerupuk Hotim di Kenjeran.

Setelah kegiatanpelatihan dilakukan maka kegiatan ini juga di memberikan bantuan dengan mendaftarkan produk kerupuk Hotim dalam memasrkan produknya secara online di Tokopedia dan Shopee. Pendampingan ini dilakukan secara intensif hingga nanti kalau sudah bisa melakukan pemasaran online secara mandiri. Sehingga kelompok UMKM Kerupuk "Hotim" saat ini sudah mampu menjual produknya melalui Toko Pedia dan Shopee, serta sudah ada pembelinya. Untuk meningkatkan penjualan maka program Pengabdian masyarakat ini juga telah membantu promosi dengan membayar TopAds di Toko Pedia Shopee agar produk bisa muncul ketika orang 
mencari produk kerupuk di dua marketplace tersebut.
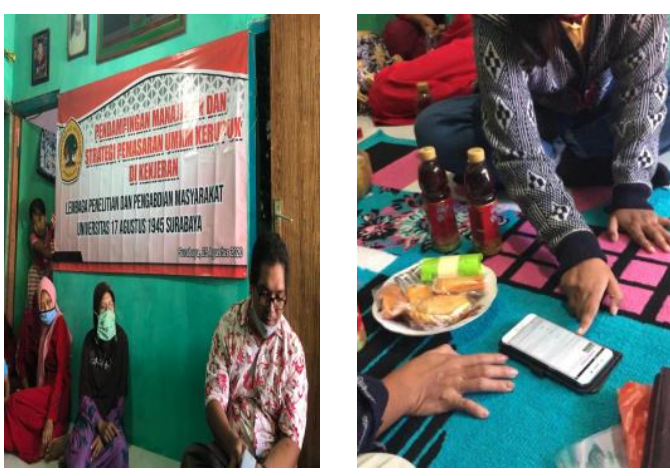

Gambar 7: Pelatihan Pemasaran Online

\section{Pelatihan Manajemen Usaha dan \\ Pembukuan Keuangan}

Pelatihan dan pendampingan manajemen usaha juga telah dilakukan guna memberikan pemahaman bagaimana mengelola usaha sehingga usaha mereka mampu bertahan dan berjalan dengan baik. Selain pendampingan manajemen usaha kegiatan ini juga telah memberikan pelatihan membuat pembukuan sederhana atas uang keluar dan masuk serta tiddak mencampur adukkan antara uang usaha dengan uang pribadi.

Menurut Kartika (2020) dengan memberikan pelatihan pengelolaan usaha, pemasaran dan pembukuan keuangan menjadikan UMKM mampu mengelola usahanya dengan efisien dan efektif, dan juga mampu memasarkan produk serta menerapkan pembukuan keuangan sehingga mengetahui keuntungan yang diperoleh dari usahanya. Pelatihan dan pendampingan manajemen usaha dan pembukuan keuangan dalam kegiatan ini telah dilakukan seperti pada gambar 8 .
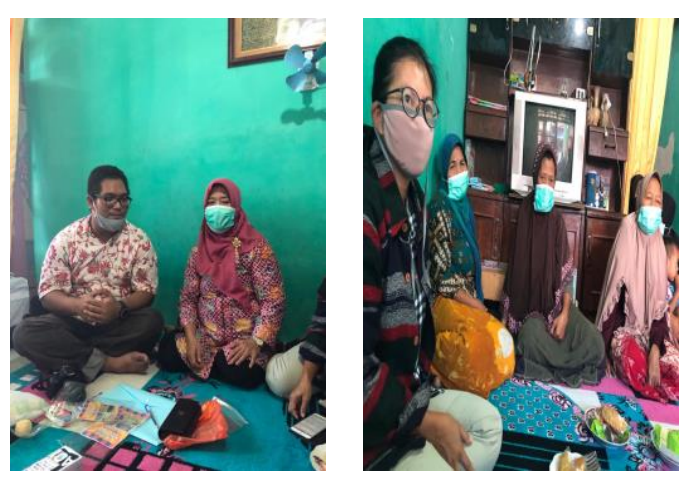

Gambar 8 menunjukkan kegiatan

Dengan diberikan pelatihan ini diharapkan UKM Kerupuk Hotim ini usahanya mulai terarah dan dilakukan secara profesional walaupun memang mitra ini adalah orang lama yang tidak berpendidikan tinggi, namun paling tidak mereka mengetahui dan melaksanakan bagaimana mengelola usaha secara lebih profesional.

Pembukuan keuangan, dimana yang selama ini belum pernah dilakukan pembukuan sama sekali, bahkan mereka merasa bahwa usahanya ini tidak pernah ada hasilnya, padahal sumber keuangan satu-satunya dalam keluarga tersebut adalah dari usaha kerupuk ini untuk memenuhi kebutuhan sehari-hari, sekolah anaknya bahkan sampai renovasi rumah menjadi lebih bagus. Mengingat kondisi seperti ini maka dalam penelitian ini diberikan pelatihan pembukuan yang sangat sederhana agar bisa diketahui berapa keuntunganya dalam satu bulan.

\section{KESIMPULAN}

Program kemitraan Bagi Masyarakat (PKM) ini, langkah pertama yang dilakukan adalah analisis situasi, dan ternyata dalam kegiatan ini menemukan beberapa permasalahan yang dihadapi oleh UMKM Kerupuk yaitu rendahnya kemampuan dalam mengelola usaha, tanpa ada perencanaa, pengorganisasi, pembukuan dan evaluasi. Disamping itu juga belum adanya strategi pemasaran 
sama sekali melainkan menunggu tengkulak yang datang membeli produknya dan di jual secara curah dengan harga yang murah, namun di masa pandemi COVID 19 penjualan sangat menunrun drastis karena tidak ada tengkulak yang datang untuk membeli kerupuk tersebut.

Kegiatan PKM ini telah dilakukan dengan memberikan pelatihan membuat kemasan memberikan Teknologi Tepat Guna untuk berjualan online berupa Handpon, Inpulse Sealer, Label produk, dan plastik kemasin, kemudian diberikan pelatihan tentang packaging, dan menjual online melalui Tokopedia dan Sophe. UKM Kerupuk kita beri nama Kerupuk Hotim dan melalui program ini sudah kami daftarkan di marketplace di Tokopedia dan Shopee. Dan saat ini sudah ada beberapa yang beli di Tokopedia tersebut karena juga sudah kita upayakan untuk beli promo atau TopAds di Toko Pedia dan Shoppee. Kegiatan lain juga dilakukan yaitu berupa pendampingan dalam bidang manajemen usaha dan pembukuan keuangan secara sederhana.

\section{DAFTAR PUSTAKA}

Abdul Majid (2013).Strategi Pembelajaran .Remaja Rosdakarya:Bandung

As'ari, Ahmad Hisyam, 2013, Peran UKM Terhadap Pertumbuhan Ekonomi Indonesia, http://ariejayuz.blogspot.com

Candraningrat, Adrianto, Yosef Richo dan Wibowo, Januar(2018), Science And Technology For Communities: Marketing Strategic Development and Packaging Design for Kelompok Tani Elok Mekarsari Surabaya. International Conference on Information Technology Applications and Systems (ICITAS). 42-46.
Candraningrat, C., Wibowo, J., \& Santoso, R. (2020). Pembuatan Digital Marketing dan Marketing Channel untuk UKM PJ Collection. JPM17: Jurnal Pengabdian Masyarakat, 5(01), 82-91.

Crismawa, A. B. (2020). Pengaruh Covid 19 terhadap UMKM di Indonesia. Gnial. http://genial.id/readnews/pengaruh-covid19-terhadapumkm-di-indonesia

Dananjaya, Utomo. 2013. Media Pembelajaran Aktif. Bandung: Nuansa Cendekia.

Fatoni, M. (2020). Sebaran Covid-19 di Indonesia hingga Selasa 30 Juni 2020 Pagi Ini, Data Rincian Kasus di 34 Provinsi. In Tribune News. Tribunnews.com.

Kartika,Yuliar, Mujanah, Siti. 2020. Peningkatan Kualitas Produk UKM Kerajinan Kulit Kerang di Kenjeran Kota Surabaya, SHARE (Journal of Service Learning), 6(01), 38-44.

Mujanah dkk. (2016). IbM Kelompok Usaha Kecil Krupuk di Kenjeran Kota Surabaya. Jurnal Pengabdian LPPM Untag Surabaya, Vol. 02, No. 01, hal $103-116$

Niko Ramadhani, 2020. Pengertian Manajemen Bisnis dan Contoh Penerapannya yang Baik. https://www.akseleran.co.id/blog/ manajemen-bisnis/

Reynaldi , Susanto, 2016. 13 Mei 2016 Peran UKM dalam Perekonomian Indonesia, reynaldisusanto.blogspot.com

Steve Troy, Jade Mountain Inc. What is Appropriate Technology? www.gdrc.org/techtran/approtech.html. di download pada tanggal 12 Agustus 2016, jam 06.02 
Yulia, 2014, Mengelola Keuangan Bagi Wirausaha Pemula, Jurnal Khatulistiwa, Vol. 4 No. 1 Maret

Kartika,Yuliar, Mujanah, Siti. 2020. Peningkatan Kualitas Produk UKM Kerajinan Kulit Kerang di Kenjeran Kota Surabaya, SHARE (Journal of Service Learning), 6(01), 38-44.

2006. Oxford English Dictionary. 2006. Little Oxford English Dictionary. California: Oxford University Press

..... 2014, Pengertian Teknologi Tepat Guna dan Contohnya, by teknologitepatguna On October 5, $2014 \quad 102239$ views www.teknologitepatguna

.......2016, Biro Pusat Statistik (BPS) ,Sensus Ekonomi 2006).

......2020, Manfaat Pemasaran Online Bagi Keberhasilan Bisnis, Redaksi
UKM, 11 Maret 2020. https://bisnisukm.com/manfaatpemasaran-online-bagikeberhasilan-bisnis.html 2015. Profil Bisnis Usaha Mikro, Kecil dan Menengah (UMKM), SME's business profile, Bank Indonesia

2018, Pengertian Teknologi tepat Guna. Di dowload pada tanggal 19 November 2020 jam 15.54 wib. https://bulelengkab.go.id/bankdata /pengertian-teknologi-tepat-guna13

2019. Pengertian, Jenis dan Manfaat Pemasaran Online. Jurnal Entrepreneur https://www.jurnal.id/id/blog/peng ertian-jenis-dan-manfaatpemasaran-online/ 